\title{
Peningkatan Ketrampilan Guru Paud Dalam Melakukan Stimulasi Deteksi Intervensi Dini Tumbuh Kembang Anak
}

\author{
Ulfatul latifah ${ }^{1}$, Indah siloka Dina ${ }^{2}$, Mutiarawati ${ }^{3}$ \\ 1,2,3Program Studi DIII Kebidanan, Politeknik Harapan Bersama \\ e-mail: ${ }^{1}$ ulfatul.bidan@poltektegal.ac.id, ${ }^{2}$ indahsiloka@yahoo.com \\ ${ }^{3}$ mutiarasutanto@gmail.com
}

\begin{abstract}
Abstrak
Di Kabupaten Tegal pada tahun 2013 terdapat pendidikan anak usia dini (PAUD) sebanyak 25,80\% dari jumlah penduduk usia 0-6 tahun dan di kecamatan Adiwerna sendiri terdapat sekitar 74 Pendidikan Anak Usia Dini (PAUD) hal ini merupakan jumlah terbanyak di kabupaten Tegal. Salah satu yang berperan dalam stimulasi deteksi dini dan intervensi tumbuh kembang pada anak adalah guru di pendidikan anak usia dini (PAUD). sehingga wilayah kecamatan Adiwerna layak untuk mendapatkan pelatihan Stimulasi Deteksi Dini dan Intervenci Dini Tumbuh Kembang pada anak (SDIDTK). Metode yang digunakan adalah pemberian materi dan praktik SDIDTK yang dilaksanakan selama 2 hari di Puskesmas Adiwerna. Dari hasil pelatihan tersebut terjadi peningkatan pengetahuan dan ketrampilan para guru sehingga mampu melakukan Stimulasi Deteksi dini dan Intervensi Tumbuh Kembang (SDIDTK) pada anak didiknya dan tidak harus menunggu petugas kesehatan yang datengke PAUD. Diharpakan kegiatan pelatihan ini dapat dilaksanakan disemua PAUD kabupaten tegal dan dukungan pemeritah sangat penting khususnya dalam hal sara dan prasana untuk mendukung kegiatan ini.
\end{abstract}

Kata kunci-SDIDTK, peningkatan keterampilan, Guru Paud

\section{PENDAHULUAN}

Pembangunan kesehatan sebagai bagian dari upaya membangun manusia seutuhnya antara lain diselenggarakan melalui upaya kesehatan anak yang dilakukan sedini mungkin sejak anak masih didalam kandungan sampai lima tahun pertama kehidupannya hal ini ditujukan untuk mempertahankan kelangsungan hidupnya sekaligus meningkatkan kualitas hidup anak agar mencapai tumbuh kembang optimal baik fisik, mental, emosional maupun social serta memiliki intelegensi majemuk sesuai dengan potensi genetiknya ${ }^{1)}$

Penelitian oleh Bloom mengenai kecerdasan yang menunjukkan bahwa kurun waktu 4 tahun pertama usia anak, perkembangan kognitifnya mencapai sekitar $50 \%$, kurun waktu 8 tahun mencapai $80 \%$, dan mencapai $100 \%$ setelah anak berusia 18 tahun. Oleh karena masa lima tahun pertama kehidupannya merupakan masa yang sangat peka terhadap lingkungan dan masa ini berlangsung sangat pendek serta tidak dapat diulang lagi, maka masa balita disebut sebagai "masa keemasan" (golden period),"jendela kesempatan "(windaw of opportunity) dan masa kritis "(critical period) $)^{2)}$

Di Indonesia jumlah balita sangat besar yaitu sekitar 10 persen dari seluruh populasi, maka sebagai calon generasi penerus bangsa, kualitas tumbuh kembang balita diIndonesia perlu mendapat perhatian serius yaitu mendapat gizi yang baik, stimulasi yang memadai serta terjangkau oleh pelayanan kesehatan berkualitas termasuk deteksi dini dan intervensi dini penyimpangan tumbuh kembang. ${ }^{1)}$

Berkaitan dengan hal tersebut stimulasi pertumbuhan dan perkembangan menjadi hal yang sangat penting bagi pertumbuhan dan perkembangan anak. Anak yang mendapat stimulasi yang terarah dan teratur akan lebih cepat berkembang dibandingkan anak yang kurang mendapat stimulasi. Dengan demikian diperlukan suatu metode untuk mendeteksi dini dan intervensi dini penyimpangan tumbuh kembang. Disinilah letak peran strategis SDIDTK. 
Salah satu program pemerintah untuk menunjang upaya tersebut adalah diterbitkannya buku pedoman pelaksanaan Stimulasi, Deteksi Dan Intervensi Dini Tumbuh Kembang Anak diTingkat Pelayanan Kesehatan Dasar ${ }^{3)}$

Stimulasi Deteksi Intervensi Dini Tumbuh Kembang (SDIDTK) anak yaitu suatu kegiatan untuk merangsang kemampuan dasar anak usia $0-6$ tahun agar anak tumbuh dan berkembang secara optimal, serta untuk menemukan penyimpangan secara dini agar lebih mudah dilakukan intervensi. Melalui kegiatan SDIDTK kondisi terparah dari penyimpangan pertumbuhan anak seperti gizi buruk dapat dicegah, karena sebelum anak jatuh dalam kondisi gizi buruk, penyimpangan pertumbuhan yang terjadi pada anak dapat terdeteksi melalui kegiatan SDIDTK. Selain mencegah terjadinya penyimpangan pertumbuhan, kegiatan SDIDTK juga mencegah terjadinya penyimpangan perkembangan dan penyimpangan mental emosional $^{4)}$

SDIDTK Diselenggarakan dalam bentuk kemitraan antara : keluarga, masyarakat dengan tenaga professional (kesehatan, pendidikan dan sosial). Indikator keberhasilan program SDIDTK adalah $90 \%$ balita dan anak prasekolah terjangkau oleh kegiatan SDIDTK pada tahun 2010. Tujuan agar semua balita umur 0-5 tahun dan anak prasekolah umur 5-6 tahun tumbuh dan berkembang secara optimal ${ }^{4)}$

Berdasarkan data kependudukan Kecamatan Adiwerna mempunyai jumlah penduduk yang paling tinggi pada tahun 2014 terdapat 128.968 jiwa dan merupakan daerah yang mempunyai kepadatan penduduk cukup tinggi. Di Kabupaten Tegal pada tahun 2013 pendidikan anak usia dini (PAUD) sebanyak 25,80\% dari jumlah penduduk usia 0-6 tahun. Di kecamatan adiwerna sendiri terdapat sekitar 74 Pendidikan Anak Usia Dini dan merupakan jumlah terbanyak di kabupaten Tegal, hal ini layak untuk dilakukan pelatihan SDIDTK sehingga para guru dapat melaksanakan sendiri setiap saat tidak harus menunggu petugas kesehatan yang datang ${ }^{5)}$

Salah satu yang berperan dalam Stimulasi deteksi dini dan intervensi tumbuh kembang anak adalah guru di pendidika anak usia dini (PAUD) yang akan melakukan deteksi dini pada anak terutama yang bersekolah di PAUD, namun kegiatan ini tidak berjalan karena terkendala dengan dana yang disediakan pemerintah tidak lancar sehingga melalui kerjasama dengan Politeknik Harapan Bersama diharapakan dapat membantu program Dinas kesehatan Kabupaten Tegal dapat optimal dan berjalan sesuai dengan harapan.

Tujuan dari kegiatan PKM ini adalah memberikan pelatihan kepada Guru Paud tentang Stimulasi Deteksi Dini dan Intervensi Dini Tumbuh Kembang Anak (SDIDTK) di Wilayah Puskesmas Adiwerna Kabupaten Tegal. Sehingga diharapkan guru paud mempunyai kemampuan untuk merangsang kemampuan dasar anak umur 0-6 tahun agar anak tumbuh dan berkembang secara optimal, serta untuk menemukan penyimpangan secara dini agar lebih mudah dilakukan intervensi.

\section{METODE}

\subsection{Sasaran Mitra}

Sasaran pemberian pelatihan Stimulasi Deteksi Dini dan Intervensi Dini Tumbuh Kembang Anak (SDIDTK) adalah 20 guru Paud di Wilayah Kecamatan Adiwerna. Kegiatan ini bekerjasama dengan Dinas Kesehatan Kabupaten Tegal, hal ini untuk membantu program pemerintah dalam upaya meningkatkan derajat kesehatan anak khusunya diWilayah Adiwerna yang mempunyai wilayah strategis dan jumlah PAUD terbanyak serta kemauan dan minat dari guru yang sangat tinggi.

\subsection{Tahapan Kegiatan}

Pada pelaksanaan kegiatan PKM dilakukan beberapa tahapan dalam proses pelaksanaannya, tahapan tersebut diperlihatkan pada Gambar 1. 


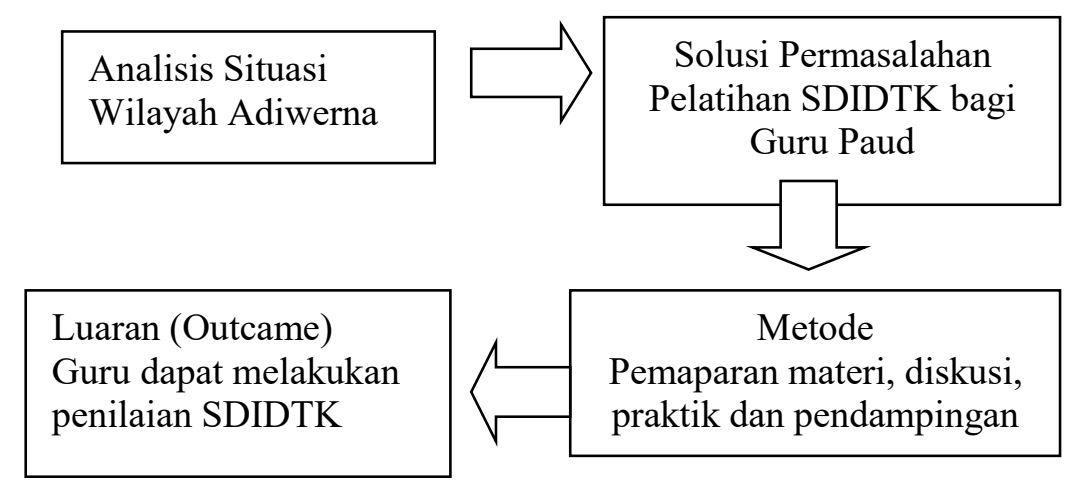

Gambar 2.1 Tahapan pelaksanaan kegiatan PKM

\section{2.1 Perencanaan Kegiatan}

Adanya program pemerintah untuk membantu meningkatkan derajat kesehatan pada anak melalui kegiatan pelatihan SDIDTK pada guru paud di wilayah Adiwerna sehingga diharapakan para guru mampu mempunyai kemampuan untuk merangsang kemampuan dasar anak umur 2-6 tahun agar anak tumbuh dan berkembang secara optimal, serta untuk menemukan penyimpangan secara dini agar lebih mudah dilakukan intervensi.

\section{2.2 Metode Pelatihan}

Metode kegiatan yang dilakukan untuk tercapainya tujuan Pengabdian Kepada Masyarakat ini adalah dengan presentasi tentang tumbuh kembang anak, pengantar dan konsep SDIDTK, diskusi, praktikum dan pendampingan cara pengisian dan penilaian Pertumbuhan dan perkembangan

\section{2.3 Pelaksanaan Kegiatan}

Kegiatan pelatihan Stimulasi Deteksi dini dan Intervensi Dini Tumbuh Kembang (SDIDTK) pada balita yang diberikan pada guru-guru PAUD dilaksanakan di Puskesmas Adiwerna pada tanggal 23-24 agustus 2016 yaitu pemberian materi dan praktik SDIDTK secara langsung dengan responden usia 2-6 tahun serta melakukan wawancara dengan orang tua responden.

\section{2.4 Evaluasi Program}

Untuk mengevaluasi program pelatihan yang dilakukan agar sesuai dengan tujuan dari luaran pelatihan yaitu adanya peningkatan kemampuan dan keterampilan Guru PAUD dalam merangsang kemampuan dasar anak umur 0-6 tahun agar anak tumbuh dan berkembang secara optimal, serta untuk menemukan adanya penyimpangan secara dini agar lebih mudah dilakukan intervensi.

\section{HASIL DAN PEMBAHASAN}

\subsection{Pelaksanaan Kegiatan}

Pelaksanaan kegiatan pelatihan SDIDTK pada guru Paud di laksanakan di Puskesmas Adiwerna yang diikuti oleh 20 orang guru Paud Wilayah Kecamatan Adiwerna, dalam kegiatan pelatihan ini dalam bentuk pemberian materi dan praktik

\subsection{Kegiatan pemberian materi / teori}

Dalam pelaksanaan kegiatan pelatihan ini diberikan beberapa materi antara lain : meteri tentang tumbuh kembang anak, pengantar dan konsep SDIDTK 


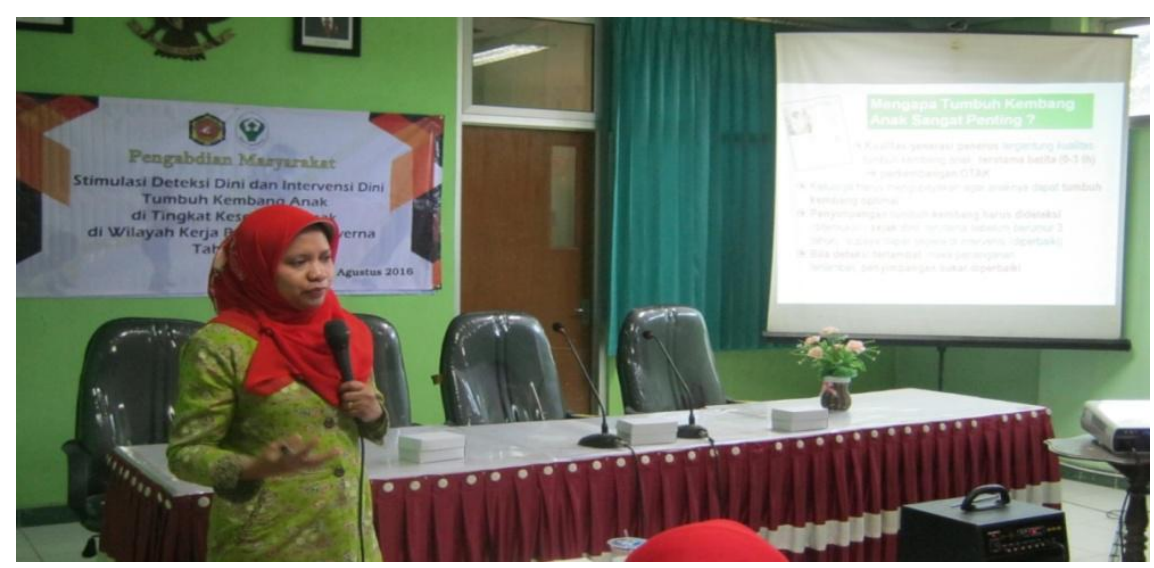

Gambar 3.1 : Pemberian materi Tumbuh kembang

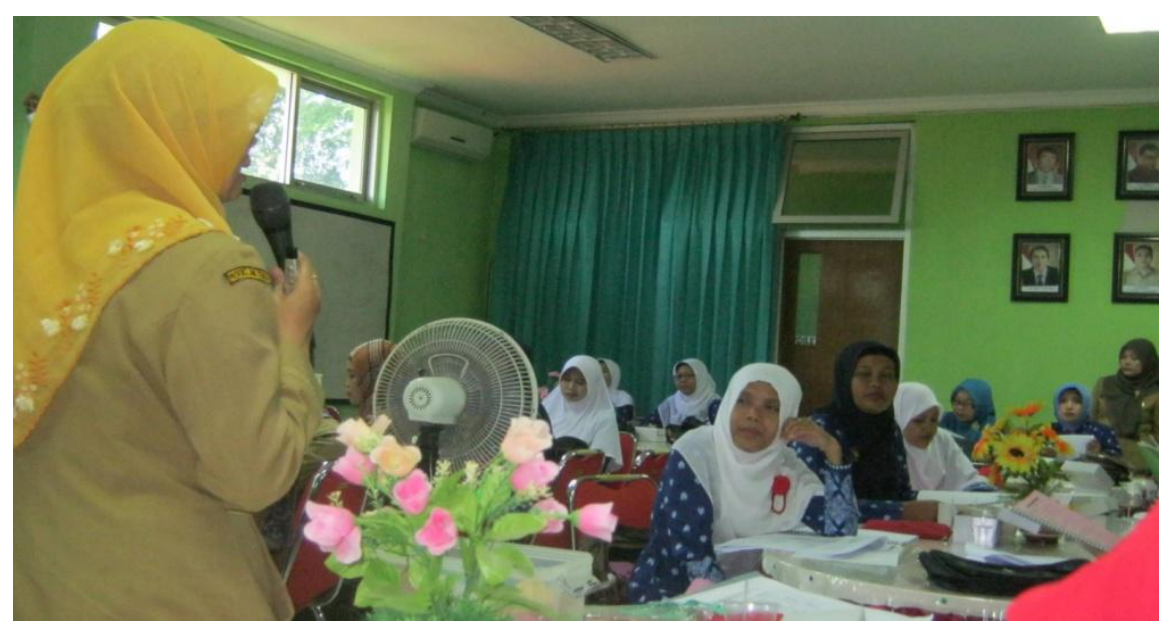

Gambar 3.2 : Pemberian materi SDIDTK

\subsection{Praktik dan Pendampingan SDIDTK}

Kegiatan praktik SDIDTK dilaksanakan secara langsung dengan melakukan penilaian pada responden anak usia 2-6 tahun secara kelompok yaitu membagi lima kelompok, masing - masing kelompok memegang satu responden mulai dari usia $2-6$ tahun, kemudian melakukan penilaian SDIDTK, dan dosen atau pelatih melakukan pendampingan pada saat dilakukan paraktik tersebut antara lain penilaian pertumbuhan dan perkembangan Penilaian pertumbuhan dengan melakukan pemeriksaan fisik (TB, BB, LK, dsb) dan penilaian perkembangan melalui Koesioner KPSP, tes daya dengar (DDT), tes penglihatan anak (TDL), gangguan perilaku (KMME)

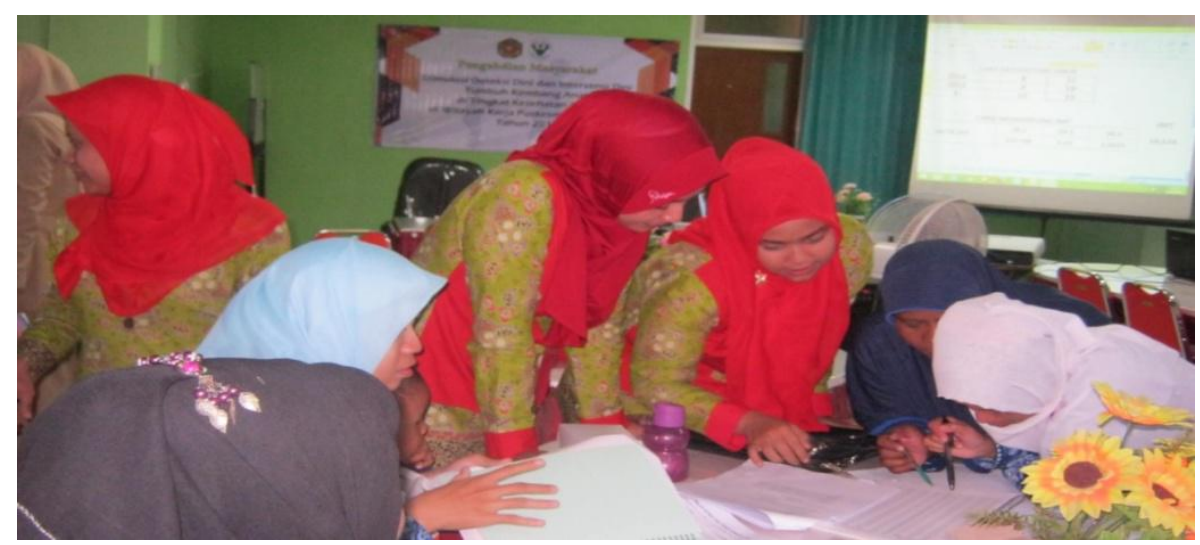

Gambar : 3.2 praktik pengisian SDIDTK 


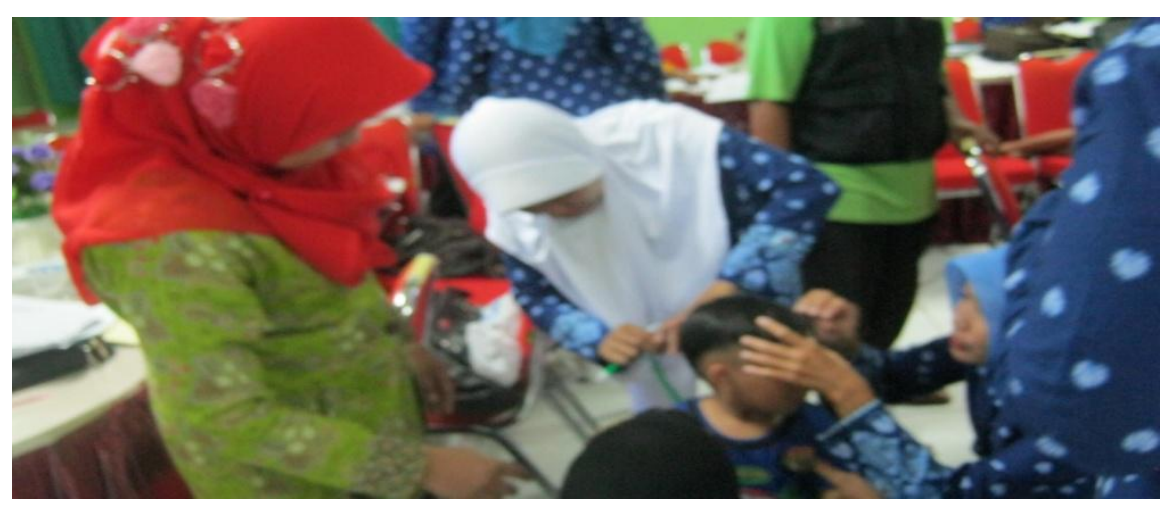

Gambar : 3.3 Praktik SDIDTK

Dari hasil obsevasi kegiatan pelatihan stimulasi, deteksi dini dan intervensi dini terhadap tumbuh kembang anak, pada 5 responden yang dilakukan penilaian secara langsung dan wawancara kepada orang tua responden menunjukkan hasil 4 responden dengan nilai perkembangan baik dan 1 responden dengan nilai kurang dari hasil penilaian stimulasi, deteksi dini dan intervensi tumbuh kembang anak. Pada responden dengan nilai kurang berdasarkan hasil wawancara dengan orang tua mengatakan kurang memperhatikan perkembangan anaknya dikarenakan orang tua atau ibu responden sibuk dengan pekerjaan dirumah sedangkan ayah bekerja diluar kota.

Hasil penelitian yang dilakukan oleh Inna SF, Rona RO 2017. Terdapat 50\% balita pada penilaian stimulasi, deteksi dini dan intervensi pada tumbuh kembang anak dengan dengan nilai baik dan $50 \%$ dengan nilai kurang. Dari pernyataan responden mengindikasikan bahwa salah satu faktor pemicu terhambatnya tingkat keberhasilan stimulasi, dini dan intervensi dini pada balita adalah tidak adanya dukungan dari orang lain khususnya keluarga. Mereka cenderung melakukannya sendiri dengan cara mencontoh orang tua terdahulu atau mencontoh orang lain disekitar lingkungan yang sudah memiliki anak ${ }^{6}$

Hartoyo (2001) melaporkan bahwa pertumbuhan anak akan berlangsung baik apabila adanya partisipasi anggota keluarga. Demikian juga halnya penelitian yang dilakukan Martianto (1998) yang melaporkan bahwa pemberian stimulasi terhadap perkembangan anak menurun dengan tidak adanya partisipasi anggota keluarga terutama ayah. Keluarga mempunyai peranan penting dan strategis dalam meningkatkan pertumbuhan dan perkembangan anak usia dini ${ }^{7}$

\section{KESIMPULAN}

Dari hasil kegiatan pelatihan mengenai Stimulasi, Deteksi dini, dan Intervensi Dini Tumbuh Kembang (SDIDTK) dapat disimpulkan bahwa terjadi peningkatan pengetahuan dan ketrampilan yang dimiliki Guru Paud di wilayah kecamatan Adiwerna Kabupaten Tegal sehingga Guru Paud dapat melakukan Stimulasi, Dekteksi dini, dan Intervensi Dini Tumbuh Kembang (SDIDTK) pada anak didiknya.

\section{SARAN}

Saran yang dapat diberikan setelah dilakukannya kegiatan Pengabdian kepada masyarakat tentang Stimulasi, Dekteksi dini, dan Intervensi Dini Tumbuh Kembang (SDIDTK) ini adalah perlu adanya dukungan dari pemerintah dalam penyediaan media atau alat untuk melakukan stimulasi dan deteksi dini untuk peserta didik serta adanya tindak lanjut pelatihan ini sehingga dapat dilakukan untuk semua guru PAUD di Kabupaten Tegal. 


\section{UCAPAN TERIMA KASIH}

Pada kesempatan ini kami mengucapkan terimakasih kepada:

1. Pusat Penelitian dan Pengabdian Masyarakat (P3M) Politeknik Harapan Bersama Tegal yang sudah mendanai kegiatan PKM ini untuk tahun pelaksanaan anggaran tahun 2016

2. Dinas Kesehatan Kabupaten Tegal sebagai mitra kami atas dukungan dana dan sarana sehingga kegiatan ini berjalan lancar

3. Puskesmas Adiwerna Kabupaten Tegal yang telah menyediakan tempat berlangsungnya kegiatan pelatihan ini

\section{DAFTAR PUSTAKA}

[1] Depkes RI. Pedoman Pelaksanaan Stimuasi, Deteksi dan Intervensi Dini Tumbuh Kembang Anak di Tingkat Pelayanan Kesehatan Dasar. Jakarta, 2007.

[2] Saidah, E.S. Pentingnya Stimulasi Mental Dini. Jurnal Ilmiah Pendidikan Anak Usia Dini. No.01.hlm. 50-55, 2003

[3] Depkes RI. 2010. Stimulasi, deteksi dan intervensi dini tumbuh kembang anak (sosialisasi buku pedoman pelaksanaan DDTK di tingkat pelayanan kesehatan dasar), Jakarta

[4] Fadilah A, Iamam CM, Ruslan DD. Manajemen pelaksanaan program SDIDTK terhadap cakupan program anak balita dan anak sekolah diwilayah kerja kota ternate 2016. Jurnal LINK,13(1),2017,20of31.ejournal.poltekkes smg.ac.id/ojs/index.php/link/article/view/2235 oleh F Abdullah -や 2017

[5] Kementrian pendidikan dan kebudayaan, 2016. Data kesatuan pendidikan anak usia dini per kecamatan Adiwerna Kabupeten Tegal.http://referensi.data.kemdikbud.go.id/index21.php?kode=032812\&level=3

[6] Inna SF, Rona RO 2017. Stimulasi, Deteksi dan Intervensi Dini Orang Tua terhadap Pencegahan Penyimpangan Pertumbuhan dan Perkembangan Anak Balita. Indonesian Journal for Health Sciences (IJHS), Vol.1, No.1, Maret 2017, Hal. 01-09

[7] Sofia,Am.2003. Psikologi Keluarga. Rajawali Press.Jakarta. 